\title{
PENGEMBANGAN SPIRITUAL QUOTIENT BAGI ANAK DALAM PERSPEKTIF PENDIDIKAN ISLAM Nurhayati IAIN Manado
}

\begin{abstract}
Abstrak
Spiritual quotient ini diartikan sebagai "kecerdasan spiritual". Yang dimaksud kecerdasan adalah prihal pertumbuhan akal dan cara berfikir yang semakin berkembang. Sedangkan spritual berasal dari kata spirit yakni rangsangan yang kuat dari dalam diri. Secara teminologis, ia dapat diartikan sebagai rangsangan keagamaan, dorongan keagamaan, yang dalam perspektif Pendidikan Islam disebutkan sebagai kesadaran fitrah beruapa nilai-nilai keagamaan yang terbawa sejak lahir. Pengertian ini juga, sejalan sebagaimana yang telah disinggung pada bagian pendahuluan bahwa potensi fitrah tersebut, meтиat aspek spiritual quotient (kecerdasan spiritual) dalam diri manusia yang terbawa sejak lahirnya.
\end{abstract}

Kata Kunci: Spiritual Quotient, Pendidikan Anak, Pendidikan Islam

\section{Latar Belakang}

Pendidikan merupakan bagian yang tidak terpisahkan dari ajaran Islam, ia merupakan bagian yang terpadu dari aspek-aspek ajaran Islam. Konsep pendidikan Islam pada hakekatnya berupaya menjadikan manusia mencapai keseimbangan keperibadiannya secara menyeluruh, dan dilakukan melalui tahapan-tahapan tertentu dan dengan pelatihan-pelatihan $\mathrm{ke}$ arah aspek kejiwaan, akal pikiran, perasaan, dan panca indra. Dalam konteks ini, maka sistem pendidikan Islam senantiasa berupaya mengembangkan dimensidimensi spiritual.

Dimensi-dimensi spiritual yang dikembangkan di dalam pendidikan Islam, sejalan dengan universalime ajaran Islam yang tidak pernah sirna ditelan masa. Ajaran Islam tersebut, membumi secara abadi melalui kegiatan pendidikan
Islam. Hal ini tersirat dari keberadaan manusia di bumi ini sejak diciptakannya, di mana Allah swt. menurunkan bantuan dan bimbingan yang merupakan pelita bagi manusia. Bimbingan itu adalah agama (Islam) yang diturunkan kepada umat manusia agar mereka mampu mengembangkan fitrah kemanusiaannya. Jadi jelaslah bahwa pendidikan Islam, mutlak dibutuhkan oleh setiap manusia, terutama dalam upaya mengembang-kan potensi fitrahnya.

Abd. Rahman Getteng menjelaskan bahwa, potensi fitrah inilah yang membedakan manusia dengan makhluk Allah lainnya, dan fitrah ini pulalah yang membuat manusia itu istimewa yang sekaligus berarti bahwa 
manusia adalah makhluk paedagogik. ${ }^{1}$ Potensi fitrah tersebut, memuat aspek spiritual quotient (kecerdasan spiritual) dalam diri manusia yang terbawa sejak lahirnya. Hal ini, juga didasarkan pada kenyataan bahwa hati, akal, dan pikiran manusia yang kesemuanya merupakan substansi kejiwaan tidak dapat berkembang sesuai dengan fitrah tanpa memperoleh pendidikan dengan baik, yakni suatu usaha sadar dan teratur serta sistematis yang diberikan dengan segaja kepada anak didik, dalam pertumbuhan dan kematangan dirinya baik jasmani maupun rohani.

Seorang anak yang telah matang jasmani dan rohaninya, berarti ia telah mencapai derajat insan kamil, yakni manusia paripurna sebagaimana yang dicita-citakan pendidikan Islam. Kaitannya dengan ini, Zakiah Daradjat menyatakan bahwa pola insan kamil adalah manusia utuh rohani dan jasmani yang dapat hidup dan berkembang secara wajar dan normal karena takwanya kepada Allah swt. Ini berarti bahwa pendidikan Islam menjadikan anak sebagai obyek peserta didik yang menekankang pentingnya pendidikan spiritual quotient, agar mampu mengamalkan ajaran Islam dalam berhubungan dengan Allah swt.

Sejalan dengan itu, Mappanganro menjelaskan bahwa letak idealnya sistem pendidikan Islam karena dalam penerapannya, menyelaraskan antara pertumbuhan spiritual keagamaan dan

${ }^{1}$ H. Abd. Rahman Getteng, Pendidikan Islam dalam Pembangunan (Ujung Pandang: Yayasan al-Ahkam, 1997), h. 14. mental, jasmani dan rohani, pengembangan individu dan masyarakat, serta kebahagiaan dunia dan akhirat. ${ }^{2}$ Untuk tujuan itu, manusia harus dididik melalui proses pendidikan Islam dengan merujuk pada ajaran Islam itu sendiri.

Pengertian Pendidikan Islam dan Spiritual Quotient

Pendidikan mengandung suatu pengertian yang sangat luas, dan menyangkut seluruh aspek kepribadian manusia, termasuk kepribadian spiritual di dalamnya. Hal ini lebih jelas lagi dipahami bila merujuk pada batasan pendidikan Islam yang lazimnya menggunakan tiga term, yakni $t a^{\prime} d \bar{\imath} b$, ta'lìm, dan tarbiyah.

$T a^{\prime} d \bar{l} b$ merupakan bentuk mas $\square$ dar dari kata addaba (أََّبَ) yang memberi memberi adab, perangai, atau kebiasan baik. ${ }^{3}$ Adab dalam kehidupan sehari-hari sering diartikan sopan santun yang mencermin-kan kepribadian seseorang. Istilah $t a^{\prime} d \bar{\imath} b$ ini dalam kaitan dengan arti pendidikan Islam, telah dikemukakan oleh Syed Muhammad Naquib al-Attās yang menurutnya bahwa inti pendidikan adalah menanamkan adab pada manusia. ${ }^{4}$ Al-At $\square \mathrm{t} \square \bar{a}$ s menjelaskan

\footnotetext{
${ }^{2}$ Mappanganro, Implementasi Pendidikan Islam di Sekolah (Cet.I; Ujung Pandang: Yayasan Ahkam, 1996), h. 10.

${ }^{3}$ Luwis Ma'luf, Al-Munjid Fi alLughah (Cet. II; Bairut: Dar al-Masyriq, 1977), h. 5. Warson al-Munawir, Kamus Al-Munawir; Arab Indonesia (Surabaya: Pustaka Progressif, 1997), h. 13.

${ }^{4}$ Wan Moh. Nor Wan Daud, The Educational Philosophi and Practice of Syed Muhammad Naquib al-Attās, diterjemahkan
} 
lebih lanjut bahwa makna adab ialah pengetahuan mencegah manusia dari kesalahan-kesalahan penilaian. Di sini adab berarti pengenalan dan pengakuan tentang hakikat bahwa pengetahuan dan wujud bersifat teratur secara hirarkis sesuai dengan berbagai tingkatan dan derajat tingkatan mereka, dan tentang tempat seseorang yang tepat dalam hubungannya dengan hakikat itu serta dengan kapasitas dan potensi jasmani, intelektual, maupun rohani seseorang. ${ }^{5}$

Bila dianalisis lebih lanjut, tentu term $t a^{\prime} d \bar{\imath} b$, ta'lìm, dan tarbiyah memiliki perbedaan yang mendasar. Dalam hal ini, ta'lim berasal dari kata 'allama (عَ) yang berarti mengajar. Jadi ta'lìm berarti pengajaran dalam kalimat bahasa Arab " diartikan "pendidikan dan pengajaran". Jadi secara etimologis, ta'lim mengandung pengertian sekedar memberi tahu, atau memberi pengetahuan, tanpa ada penekanan pada pembimbingan moralitas sebagaimana yang terkandung dalam term addaba yang telah dijelaskan. Atau dengan kata lain, term ta'lim tidak mengandung arti pembinaan kepribadian.

Dapatlah dipahami bahwa ta'tìm merupakan usaha untuk menjadikan seseorang mengenal tanda-tanda yang

oleh Hamid Fahmi, dkk, dengan judul Filsafat dan Praktik Pendidikan Islam Syed M. Naquib al-Attas (Cet. I; Bandung: 1998), h. 61.

${ }^{5}$ Uraian lebih lanjut, lihat Wan Moh. Nor Wan Daud, op. cit., h. 62-63. Lihat juga Muhammad Naquib al-Attās, Islam Skularism diterjemahkan oleh Karsido Djoyoswarno dengan judul Islam Sekularisme (Jakarta: Pustaka Amani, 1991), h. 222. membedakan antara satu dengan lainnya, dan mempunyai pengetahuan serta pemahaman yang benar tentang sesuatu. Jadi term ta'lìm mempunyai konotasi khusus dan merujuk pada ilmu pengetahuan semata.

Selanjutnya term tarbiyah, di samping merujuk pada akar kata rabā (bertambah dan bertumbuh), juga merujuk pada akar kata rabiya (tumbuh dan berkembang), serta merujuk pada akar kata rabba (memperbaiki, mengusai, dan memimpin). ${ }^{6}$ Term tarbiyah juga, berasal dari kata $r a b(a l$-rab) yang berarti mengantarkan sesuatu kepada kesempurnaan secara bertahap atau membuat sesuatu mencapai kesempurnaannya secara bertahap dan berangsur. ${ }^{7}$

Dengan melihat uraian di atas, kelihatan bahwa asal kata dan arti term tarbiyah bermacam-macam. Namun para pakar pendidikan Islam telah bersepakat bahwa arti tarbiyah adalah "pendidikan" dan kata ini mengandung makna yang sangat luas. Bisa berarti mengasuh, memelihara, menumbuh kembangkan segala potensi yang dimiliki manusia ke arah kesempurnannya, dan banyak ayat yang menunjuk pada arti-arti yang demikian

\footnotetext{
${ }^{6}$ Jamāl al-Dīn Ibn Manżūr, Lisān al'Arab, jilid I (Mesir: Dār al-Mis $\square$ riyah, t.th), h. 384 dan 389.

${ }^{7}$ Al-Rāgib al-As $\square$ fahāniy, Mu'jam alMufradāt Alfāz $\square$ al-Qur'ān (Bairut: Dār alFikr, t.th), h. 189.
} 
ini. ${ }^{8}$ Di samping itu, ditemukan hadis yang redaksinya sebagai berikut :

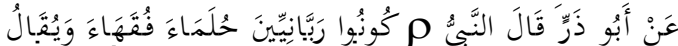

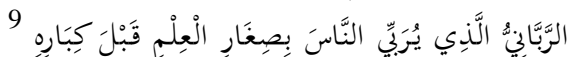

Artinya :

Dari Abū Żar, Nabi saw bersabda, jadilah kamu para pendidik yang penyantun, faqih dan berilmu pengetauan. Dikatakan juga, jadilah predikat rabbaniy apabila seseorang telah mendidik manusia dengan ilmu pengetahuan, dari sekecil-kecilnya sampai yang paling tinggi.

Berkenaan dengan itu, term tarbiyah adalah padanan dari term rabbāniyyīn yang mengandung arti proses transformasi ilmu dan sikap pada didik untuk menjadi penyantun, memahami, dan menghayati sesuatu untuk sampai pada derajat tinggi dan kepribadian yang mulia. Itu berarti bahwa pendidikan dengan term tarbiyah adalah bermula dari proses pengenalan (introducing), hafalan (memorazing), kemudian ber-lanjut terus menerus sampai pada proses pemahaman (analizing), dan kan terbentuk nantinya kepribadian muslim yang mulia, yaitu dengan dengan derajat yang tinggi (taqwa).

Dapat dirumuskan bahwa tarbiyah mempunyai pengertian yang lebih luas. Karena itulah, term tarbiyah selama ini lebih banyak digunakan ketimbang $t a^{\prime} d \bar{\imath} b$ dan ta'lìm dalam mengkonsepsikan pen-

${ }^{8}$ Lihat misalnya QS. al-Fātihah (1): 2; QS. Ali Imrān (3): 79; QS. al-Isrā' (17): 24; QS. al-Syuarā' (26): 18;

${ }^{9}$ Al-Bukhāri, op. cit., $\quad$ CD. Rom Hadis, kitab al-'Ilm, hadis 1 . didikan Islam, al-tarbiyah al-islāmiyah (التربية الإسلامية).

Selanjutnya tentang konsep batasan terminologis pendidikan Islam yang komprehensif banyak dikemukakan para pakar, misalnya sebagai berikut :

1. Abd. Rahmān al-Nahlāwiy :

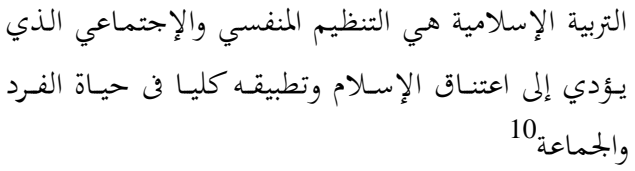

Artinya :

Pendidikan Islam ialah pengaturan pribadi dan masyarakat yang karenanya dapatlah menunaikan (ajaran) Islam secara utuh dan menyeluruh, baik dalam kehidupan individu maupun masyarakat.

2. Mustāfa al-Ghulāyaini sebagai mana dikutip Djamaluddin dan Abdullah Aly :

Pendidikan Islam ialah menanmkan akhlak mulia di dalam jiwa anak dalam pertumbuhannya dan menyiraminya dengan air petunjuk dan nasehat, sehingga akhlak itu menjadi salah satu kemampuan (meresap dalam) jiwanya, kemudian buahnya berujud keutamaan, kebaikan, dan

${ }^{10}$ Abd. Rahmān al-Nahlāwiy, Ushūl al-Tarbiyat al-Islāmiyah wa Asālibuhā fì alBayt wa al-Madrasah wa al-Mujtamah (Cet. I; Bairūt: Dār al-Fikr, 1983), h. 21. 
cinta bekerja untuk memanfaatkan tanah air. ${ }^{11}$

3. Hasan Langgulung :

Pendidikan Islam adalah sebagai proses penyiapan generasi muda untuk menjadi peranan, memindahkan pengetahuan dan nilai-nilai Islam yang diselaraskan dengan fungsi manusia untuk beramal di dunia dan memetik hasilnya di akhirat. ${ }^{12}$

4. Mappanganro :

Pendidikan Islam adalah usaha yang dilakukan secara sadar dengan membimbing, mengasuh anak atau peserta didik agar dapat menyakini, memahami, menghayati dan mengamalkan ajaran-ajaran Islam. $^{13}$

Berkenaan dengan definisidefinisi di atas, dipahami bahwa pendidikan Islam erat kaitannya dengan upaya penanaman spiritual quotient kepada obyek didik/peserta didik.

Istilah spiritual quotient ini diartikan sebagai "kecerdasan spiritual". Yang dimaksud kecerdasan adalah prihal pertumbuhan akal dan cara berfikir yang semakin berkembang. ${ }^{14}$ Sedangkan

${ }^{11}$ Djamaluddin dan Abdullah Aly, Kapita Selekta Pendidikan Islam (Cet. I; Bandung: Pustaka Setia, 1998), h. 10-11

${ }^{12}$ Hasan Langgulung, Beberapa Pemikiran tentang Pendidikan Islam (Bandung: al-Ma'arif, 1980), h. 94.

${ }^{13}$ Mappanganro, op. cit., h. 10.

${ }^{14}$ Departemen Pendidikan Nasional, Kamus Besar Bahasa Indonesia (Jakarta: Balai Pustaka, 2002), h. 209. spritual berasal dari kata spirit yakni rangsangan yang kuat dari dalam diri. Secara teminologis, ia dapat diartikan sebagai rangsangan keagamaan, dorongan keagamaan, yang dalam perspektif Pendidikan Islam disebutkan sebagai kesadaran fitrah beruapa nilai-nilai keagamaan yang terbawa sejak lahir. ${ }^{15}$ Pengertian ini juga, sejalan sebagaimana yang telah disinggung pada bagian pendahuluan bahwa potensi fitrah tersebut, memuat aspek spiritual quotient (kecerdasan spiritual) dalam diri manusia yang terbawa sejak lahirnya.

Potensi fitrah memuat aspek kesucian jiwa dalam diri manusia yang terbawa sejak lahirnya. Hal ini, juga didasarkan pada kenyataan bahwa hati, akal, dan pikiran manusia yang kesemuanya merupakan substansi kejiwaan tidak dapat berkembang sesuai dengan fitrah tanpa memperoleh pendidikan dengan baik, yakni suatu usaha sadar dan teratur serta sistematis yang diberikan dengan segaja kepada anak didik, dalam pertumbuhan dan kematangan dirinya baik jasmani maupun rohani.

Dapatlah dirumuskan bahwa pendidikan Islam merupakan bimbingan yang dilakukan oleh seseorang dalam upaya perwujudan kepribadian spritual yang cerdas bagi peserta didiknya. Dengan begitu, pendidikan Islam lebih banyak ditujukan pada perbaikan sikap mental yang akan berwujud dalam amal perbuatan, baik dalam segi keperluan diri

${ }^{15}$ Abd. Rahman al-Nahlawi, op. cit., h. 17. Lihat juga Zakiah Darajat, Pendidikan Mental Keagamaan (Jakarta: Rineka, 1997), h. 23. 
sendiri maupun orang lain. Pada sisi lain, pendidikan Islam tidak hanya bersifat teoritis saja, tetapi juga praktis. Jadi pendidikan Islam, adalah sekaligus pendidikan iman dan pendidikan amal yang dapat mendekatkan diri pada Allah swt.

Urgensi Pendidikan Islam dalam Upaya Penanaman Spiritual Quotient Pada Anak

Demikian pentingnya pendidikan Islam dalam upaya penanaman spiritual quotient, maka bukan secara kebetulan bila ayat yang pertama kali diturunkan oleh Allah swt. kepada Nabi Muhammad saw. adalah berkaitan tentang urgensi pendidikan, yakni iqra', perintah membaca sebagaimana firman Allah swt dalam QS. al-Alaq (96): 1-5 :

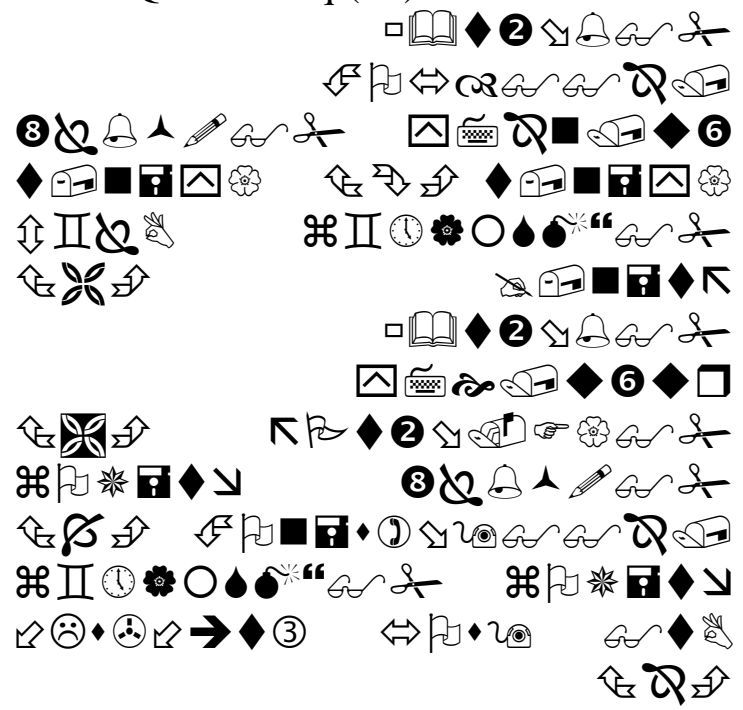

Terjemahnnya :

Bacalah dengan (menyebut) nama Tuhanmu Yang menciptakan, Dia telah menciptakan manusia dari segumpal darah. Bacalah, dan Tuhanmulah Yang Maha Pemurah, Yang mengajar (manusia) dengan perantaraan kalam. Dia mengajarkan kepada manusia apa yang tidak diketahuinya. ${ }^{16}$

Firman Allah swt ini, mengandung pesan tentang dasar pendidikan yang memuat pesan-pesan pentingnya spiritual quotient. Dalam hal ini, Nabi saw. yang ummi melalui ayat tersebut, ia diperintahkan untuk belajar membaca. Yang dibaca itu objeknya bermacammacam, ada ayat-ayat yang tertulis (ayah Alquraniyah), dan ada pula pula ayat-ayat yang tidak tertulis (ayah al-kawniyah).

Hasil yang ditimbulkan dengan usaha belajar membaca ayat-ayat qur'aniyah, dapat menghasilkan ilmu agama seperti fikih, tauhid, akhlak dan semacamnya. Sedangkan hasil yang ditimbulkan dengan usaha membaca ayatayat kawniyah, dapat menghasilkan sains seperti fisika, biologi, kimia, astronomi dan semacamnya. Dapatlah dirumuskan bahwa ilmu yang bersumber dari ayatayat qur'aniyah dan kawniyah, harus diperoleh melalui proses belajar membaca.

Kata iqra' atau perintah membaca dalam ayat di atas, terulang dua kali yakni pada ayat 1 dan 3 karena menurut penulis bahwa, perintah pertama penekanannya adalah pengenalan kepada Allah sebagai Tuhan Pencipta atas segala sesuatunya, termasuk alam dan manusia. Sedangkan pada perintah yang kedua menekankan bahwa sumber segala ilmu pengetahuan adalah Tuhan Yang Maha Tahu segalanya, sehingga implikasinya

\footnotetext{
${ }^{16}$ Departemen Agama RI, Alquran dan Terjemahnya (Jakarta: Proyek Pengadaan Kitab Suci Alquran, 1992), h. 1079.
} 
adalah sesuatu ilmu dipandang benar apabila dengan ilmu itu ia sudah sampai mengenal Tuhan (ma'rifatullah).

Untuk mengenal Tuhan dengan segala ciptaan-Nya, apa yang terbentang di seluruh jagat dan alam raya ini sebagai ayat-ayat Allah swt. juga perlu dibaca oleh manusia guna ma'rifatullah. Maka dari itu Tuhan memberikan kepada manusia alat-alat potensial yang dapat mencerdaskan manusia sebagaimana di dalam QS. al-Nahl (16): 78 :

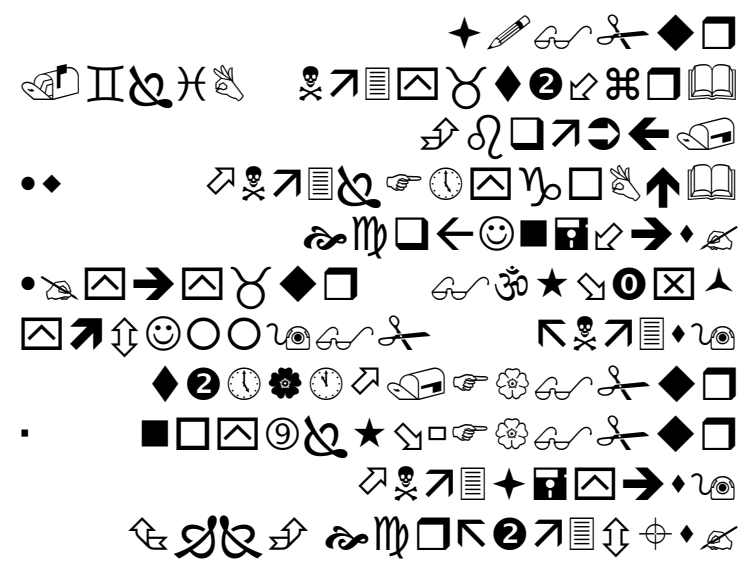

Terjemahnya :

Dan Allah mengeluarkan kamu dari perut ibumu dalam keadaan tidak mengetahui sesuatupun, dan Dia memberi kamu pendengaran, penglihatan dan hati, agar kamu bersyukur. ${ }^{17}$

Klausa “"لَ تَعْلَمُونَ شَيْيًَا dalam ayat di atas mengandung makna bahwa setiap anak di saat dilahirkannya, tidak mengetahui sesuatu tentang sedikit pun,

\footnotetext{
${ }^{17}$ Departemen Agama RI, Alquran dan Terjemahnya (Jakarta: Proyek Pengadaan Kitab Suci Alquran, 1992), h. 413
}

dan untuk mengetahui yang tidak diketahuinya itu, maka Allah swt. memberikan alat potensial untuk mencerdasrkan dirinya berupa al-sam'u (pendengaran), al-abshāra (penglihatan), dan al-afidah (hati untuk memahami).

Kata al-sam'u dan al-abshār dalam arti indera manusia, ditemukan dalam Alquran secara bergandengan sebanyak tiga belas kali. ${ }^{18}$ Kata al-sam'u selalu digunakan dalam bentuk tunggal, dan selalu mendahului kata al-abshar. Pernyataan ini sekaligus menegaskan bahwa al-sam'u sebagai salah satu alat indera manusia memiliki posisi penting bagi manusia itu sendiri dalam memperoleh ilmu pengetahuan melalui pendidikan. Setelah kedua kata tadi, disebutkan lagi al-af'idah yang juga merupakan bentuk jamak. Ini berarti bahwa banyak pengetahuan yang dapat diraih setiap orang, namun sebelumnya ia harus menggunakan pendengarannya dan penglihatannya terlebih dahulu secara baik.

Allah swt. memberi pendengaran, penglihatan dan hati kepada manusia, agar dipergunakan untuk merenung, memikirkan, dan mem-perhatikan apaapa yang ada disekitarnya. Kesemuanya ini, merupakan motivasi bagi segenap umat manusia untuk mencari ilmu pengetahuan melalui jalur pendidikan, dan sekaligus merupakan kewajiban bagi setiap muslim, sejak kecilnya sampai berusia lanjut. Hal ini, didasarkan atas ungkapan yang oleh sementara pakar pendidikan dianggap sebagai hadis Nabi

\footnotetext{
${ }^{18}$ Lihat Muhammad Fu'ad 'Abd. al-
} Bāqi, op. cit., h. 456-457 


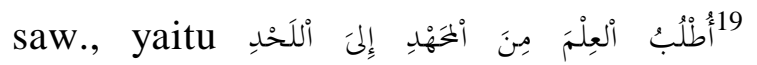
(Tuntutlah ilmu dari buaian hingga liang lahat). Lebih dari itu, ditemukan pernyataan Nabi saw. yang mensejajarkan orang yang menuntut ilmu dengan orang yang berjihad di jalan Allah. Redaksi hadis tersebut, adalah :

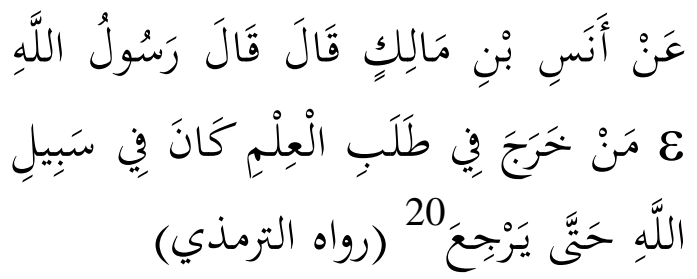

Artinya :

Dari Anas bin Mālik berkata : Rasulullah saw. bersabda : Barang siapa yang keluar untuk mencari ilmu, maka yang bersangkutan berada di jalan Allah sampai ia kembali dari kegiatan menuntut ilmu. (HR. Turmūziy)

Di samping nas-nas yang berkenaan dengan urgensi pendidikan dalam hal upaya penanaman spiritua quotient sebagaimana yang telah disebutkan, masih banyak ditemukan firman Allah swt., maupun hadis Nabi saw. yang secara implisit sangat sejalan dengan nas-nas tersebut. Itu berarti bahwa pendidikan Islam bagi setiap anak

\footnotetext{
${ }^{19}$ Hadis di atas, memang penullis tidak menemukaannya dalam al-Kutub al-Tis'ah, tetapi telah menjadi mayshur di kalangan mayarakat dan sering dikemukakan para pakar pendidikan sebagai dalil tentang urgensi pendidikan Islam.

${ }^{20} \mathrm{Abu}$ Isa Muhammad bin Isa alTurmuzi, Sunan al-Turmūzi, dalam CD. Rom Hadī£ al-Syarīf al-Kutub al Tis'ah, Kitab al' $\mathrm{Ilm}$ hadis nomor 2571.
}

dalam upaya peningkatan dan pengembagan kecerdasan spiritualnya merupakan kewajiban.

Pendidikan Islam di samping sebagai kewajiban, mutlak dibutuhkan oleh setiap anak muslim untuk kepentingan eksistensinya. Jadi pendidikan Islam dengan upaya penanaman spiritual quotient tidak dapat dipandang sebelah mata, terutama di saat memasuki era globalisasi yang penuh tantangan. Bahkan kalau dilihat dalam sudut agama, pendidikan Islam yang menekankan aspek spiritual quotient tersebut memiliki format pemeliharaan, pemanfaatan, dan pengembangan fitrah kemanusian dalam mengantisipasi krisis spiritual di era globalisasi, karena inti pendidikan yang diajarkan Islam adalah untuk pemenuhan jati diri manusia atau esensi kemanusiaan di hadapan Allah swt.

\section{Implementasi Pendidikan Islam dalam Penanaman Spiritual Quotient pada Anak}

Para pakar pendidikan Islam merumuskan bahwa pendidikan yang tertuju pada pencapaian perkembangan spiritual quotient dalam perubahan individu dan secara utuh, yang berlangsung dalam hidup, terbangun dari tiga komponen, yaitu; landasan-landasan pendidikan; isi pendidikan, dan cara-cara pendidikan.

Landasan-landasan pendidikan atau foundations of education, yakni landasan pemikiran bahwa pendidikan spiritual quotient bagi setiap anak itu penting, karena anak-anak tidak semua mendapatkan pendidikan baik di rumah maupun di sekolah atau tidak bersekolah sama sekali. Selanjutnya, isi pendidikan 
atau contents of education berkenaan dengan persediaan kultural yang berupa pengetahuan seorang anak serta perkembangan kecerdasannya dari keusangan pengetahuan. Ini berarti bahwa materi-materi yang berkenaan denga spiritualisme dalam proses pembelajaran pada pendidikan, harus didesain secara efektif. Kemudian mengenai cara-cara pendidikan atau means of education adalah berkenaan dengan cara-cara komunikasi verbal dan nonverbal, alatalat bantu belajar mengajar baru, dan sebagainya. Komunikasi verbal dan nonverbal terletak pada kemampuan anak dari segi head, heart dan hand. Sedangkan alat-alat pendidikan sepenuhnya diserahkan pada masyarakat dengan keadaaan yang bervariasi, dari keadaan yang sederhana sampai keadaan yang dapat memenuhi persyaratan. ${ }^{21}$

Dengan merujuk pada komponen-komponen pendidikan spiritual quotient itu maka dalam pendidikan Islam dikenal beberapa konsep implementasi dalam upaya penanaman nilai-nilai kecerdasan spiritual pada anak yang terutama sekali dibebankan pada keluarga (pendidikan informal), dan sekolah (pendidikan formal).

Pada sisi lain, pendidikan spiritual quotient juga turut mem-beri pengaruh terhadap proses pertumbuhan dan perkembangan anak dalam segala hal, dan termasuk di dalamnya memberi

\footnotetext{
${ }^{21}$ Tery Page, et. all, International Dictionary of Education (Camridge: The MIT Press, 1980), h. 206. Lihat juga H. Fuad Ihsan, Dasar-dasar Kependidikan (Cet. I; Jakarta: Rineka Cipta, 1997), h. 44
}

pengaruh terhadap motivasi belajar anak sampai akhir hayatnya. Terkait dengan ini, Wlodkowski dan Jaynes menyatakan bahwa "para orang tua hendaknya tampil sebagai faktor pemberi pengaruh utama bagi motivasi belajar anak". ${ }^{22}$ Sejalan dengan kepentingan perkembangan spiritual quotient bagi anak-anak, maka orang tua mereka menyekolahkannya dan karena itu pendidikan di sekolah adalah termasuk rangkaian pendidikan spiritual quotient.

Dalam perspektif Islam, implementasi pengembangan spiritual quotient adalah berdasarkan fase-fase perkembangan anak itu sendiri. Artinya, proses pendidikan untuk mencerdaskan kecerdasan spiritual anak disesuaikan dengan pola dan tempo, serta irama perkembangan yang dialami oleh seseorang sampai akhir hayatnya, yakni ;

1. Masa al-Janin (usia dalam kandungan)

Masa al-Janin, tingkat anak yang berada dalam kandungan dan adanya kehidupan setelah adanya roh dari Allah swt. ${ }^{23}$ Pada usia 4 bulan, pendidikan dapat diterapkan dengan istilah "pranatal" atau juga dapat dilakukan sebelum ada itu menjadi janin yang disebut dengan pendidikan "prakonsepsi". Karena itu, ibu sebagai orang tua yang

\footnotetext{
${ }^{22}$ Raymond Wlodkowski J dan Judith H. Jaynes, Eager to Learn, diterjemahkan oleh M. Chairul Annam dengan judul, Motivasi Belajar (Jakarta: Cerdas Pustaka, 2004), h. 21

${ }^{23}$ Lihat Zainuddin et. al., Seluk Beluk Pendidikan dari al-Ghazali (Cet. I; Jakarta: Bumi Aksara, 1991), h. 69.
} 
mengandung anak, hendaklah mempersiapkan kondisinya fisik maupun psikisnya, sebab sangat menentukan dan ber-pengaruh terhadap proses kelahiran anak nanti. Selain komsumsi makanan dan ketenangan emosional ibu juga perlu dijaga (ketenangannya).

2. Masa bayi (usia 0-2 tahun)

Pada tahap ini, orang belum memiliki kesadaran dan daya intelektual, ia hanya mampu menerima rangsangan yang bersifat biologis dan psikologis melalui air susu ibunya. Karena demikian halnya, maka dalam fase ini belum dapat diterapkan interaksi edukatif secara langsung (direct), karena itu proses edukasi dapat dilakukan menurut Islam adalah memberi adzan di telinga kanan dan iqomah di telinga kiri ketika baru lahir, memberi nama yang baik ketika diaqiqah. Jadi, fase hari-hari pertama dan mingguminggu pertama dari kelahirannya, sudah mesti diperkenalkan kalimat tauhid, selanjutnya memberi nama yang bernuangsa islami.

3. Masa kanak-kanak(usia 2-12 tahun) Pada fase ini, seseorang mulai memiliki potensi-potensi biologis, paedagogis. Oleh karena itu, mulailah diperlukan adanya pembinaan, pelatihan, bimbingan, pengajaran dan pendidikan yang disesuaikan dengan bakat dan minat atau fitrahnya. Dalam hal ini, ketika berumur enam tahun hendaklah dipisahkan dari tempat tidurnya dan memerintahkan untuk shalat ketika berumur tujuh tahun. Proses pembinaan dan pelatihan lebih efektif lagi bila dalam usia tujuh tahun disekolahkan pada Sekolah Dasar. Hal tersebut karena pada fase ini, seseorang mulai aktif dan mampu mem-fungsikan potensi-potensi indranya walaupun masih pada taraf pemula.

4. Masa puber (usia 12-20 tahun)

Pada tahap ini, seseorang mengalami perubahan biologis yang drastis, postur tubuh hampir menyamai orang dewasa walaupun taraf kematangan jiwanya belum mengimbanginya. Pada tahap ini, seseorang mengalami masa transisi, masa yang menuntut seseorang untuk hidup dalam kebimbangan, antara norma masyarakat yang telah melembaga agaknya tidak cocok dengan pergaulan hidupnya sehari-hari, sehingga ia ingin melepaskan diri dari belenggu norma dan susila masyarakat untuk mencari jati dirinya, ia ingin hidup sebagai orang dewasa, diakui, dan dihargai, tetapi aktivitas yang dilakukan masih penuh kekanakkanakan, sehingga acapkali orang tua masih mengikat dan membatasi kehidupannya agar nantinya dapat mewarisi dan mengembangkan hasil yang diperoleh orang tuanya. Proses edukasi fase puber ini, hendaknya dididik mental dan jasmaninya misalnya mendidik dalam bidang olahraga ${ }^{24}$ dan

\footnotetext{
${ }^{24}$ Demikian maksud sabda Nabi saw. "علمـو او لادكـم بالرمـاح و اصـباح " Hadis tersebut dikutip dari Ahmad al-Hasyimiy, Mukhtār
} 
memberikan suatu model, mode dan modus yang Islami, sehingga ia mampu hidup "remaja" di tengah-tengah masyarakat tanpa meninggalkan nilai-nilai normatisisme Islam.

Menurut ajaran Islam menuntut ilmu itu wajib, ${ }^{25}$ karena disamping ilmu itu berkembang secara pesat dan takkan habis-habis dikaji maka pendidikan dengan fokus pengembangan spiritual anak dalam hal ini adalah sebenarnya merupakan kewajiban bagi setiap muslim. Dalam sisi lain, karena Islam juga memang mendambakan umatnya betulbetul tidak berhenti belajar dan memulainya sedini mungkin.

\section{Kesimpulan}

Penanaman spiritual quotient bagi setiap anak sangat penting, dan karena itu bukan secara kebetulan bila ayat yang pertama kali diturunkan oleh Allah swt adalah tentang urgensi iqra', perintah membaca. Untuk tujuan itu, maka Allah swt juga memberikan alat-latar potensial untuk mendukung kecerdasan anak, yakni diberikannya al-sam'u (alat pendengaran), al-abshāra (alat penglihatan), dan al-afidah (hati sebagai alat untuk memahami).

Implementasi pendidikan Islam yang tertuju pada pencapaian perkembangan spiritual quotient memiliki konsep tersendiri sejalan dengan usia kematangan pertumbuhana anak, yakni mulai sejak dalam

Ahādits al-Nabawiy (Mesir: Makatbah alTijariyyah, t.th.), h. 200.

${ }^{25}$ Dalam hadis dikatakan “ طلب العلم "فريضة على كل مسلم ومسلمة kandungan, kemudian setelah lahir diazankan, di beri nama yang baik, dalam umur tujuh tahun diajarkan shalat, dan diberikan sangksi bila meninggalkan shalat, demikian seterusnya sehingga nilai-nilai kecerdasan dan keagamaan pada anak tertanam dengan baik. 


\section{DAFTAR PUSTAKA}

Al-Qur'an al-karim

Arifin H. Muzayyyin, Filsafat Pendidikan Islam. Jakarta: Bumi Aksara, 2005.

Al-As $\square$ fahāniy, Al-Rāgib. Mu'jam al-Mufradāt Alfāz $\square$ al-Qur'ān. Bairut: Dār alFikr, t.th.

Al-Attās, Muhammad Naquib. Islam Skularism diterjemahkan oleh Karsido Djoyoswarno dengan judul Islam Sekularisme. Jakarta: Pustaka Amani, 1991

Darajat, Zakiah. Pendidikan Mental Keagamaan. Jakarta: Rineka, 1997.

Departemen Agama RI, Alquran dan Terjemahnya (Jakarta: Proyek Pengadaan Kitab Suci Alquran, 1992.

Departemen Pendidikan Nasional, Kamus Besar Bahasa Indonesia. Jakarta: Balai Pustaka, 2002.

Djamaluddin dan Abdullah Aly, Kapita Selekta Pendidikan Islam. Cet. I; Bandung: Pustaka Setia, 1998.

Getteng, H. Abd. Rahman. Pendidikan Islam dalam Pembangunan. Ujung Pandang: Yayasan al-Ahkam, 1997.

Al-Hasyimiy, Ahmad. Mukhtār Ahādits al-Nabawiy. Mesir: Makatbah alTijariyyah, t.th.

Ibn Manżūr, Jamāl al-Dīn. Lisān al-'Arab, jilid I. Mesir: Dār al-Mis $\square$ riyah, t.th.

Ihsan, H. Fuad. Dasar-dasar Kependidikan. Cet. I; Jakarta: Rineka Cipta, 1997.

Langgulung, Hasan. Beberapa Pemikiran tentang Pendidikan Islam. Bandung: alMa'arif, 1980.

Ma'luf, Luwis. Al-Munjid Fi al-Lughah. Cet. II; Bairut: Dar al-Masyriq, 1977

Mappanganro, Implementasi Pendidikan Islam di Sekolah. Cet.I; Ujung Pandang: Yayasan Ahkam, 1996.

Al-Nah $\square$ lāwiy, 'Abd. Rah $\square$ mān. Us $\square \bar{u} l$ al-Tarbiyat al-Islāmiyah wa Asālibuhā fī al-Bayt wa al-Madrasah wa al-Mujtamah. Cet. I; Bairūt: Dār al-Fikr, 1983. 
Page, Tery., et. all, International Dictionary of Education. Camridge: The MIT Press, 1980.

Al-Sijistāniy, Abū Dāwud Sulaiman ibn al-Asy'as. Sunan Abū Dāwud, juz IV. Beirut: Dār al-Fikr, 1968.

Al-Turmuzi, Abu Isa Muhammad bin Isa. Sunan al-Turmūzi, dalam CD. Rom Hadī£ al-Syarīf al-Kutub al Tis'ah.

Wlodkowski J, Raymond dan Judith H. Jaynes, Eager to Learn, diterjemahkan oleh M. Chairul Annam dengan judul, Motivasi Belajar. Jakarta: Cerdas Pustaka, 2004.

Zainuddin et. al., Seluk Beluk Pendidikan dari al-Ghazali. Cet. I; Jakarta: Bumi Aksara, 1991. 